\title{
Integration of Remote Sensing Technology Using Sentinel-2A Satellite images For Fertilization and Water Pollution Analysis in Estuaries Inlet of Semarang Eastern Flood Canal
}

\author{
Sawitri Subiyanto ${ }^{1 *}$, Zainab Ramadhanis ${ }^{1}$, Aditya Hafidh Baktiar ${ }^{1}$ \\ ${ }^{1}$ Department of Geodesy Engineering, Faculty of Engineering, Diponegoro University, Semarang
}

\begin{abstract}
One of the waters that has been contaminated by industrial waste and domestic waste is the waters in estuaries inlet of Semarang Eastern Flood Canal which is the estuary of the river system, which passes through the eastern city of Semarang which is dense with residential and industrial. So it is necessary to have information about the assessment of water quality in Estuaries Inlet of Semarang Eastern Flood Canal. Remote sensing technology can analyze the results of recording the spectral characteristics of water with water quality parameters. One of the parameters for assessing water quality is Chlorophyll-a and Total Suspended Solid, can be estimated through remote sensing technology using multispectral Sentinel-2A Satellite images. In this research there are 3 algorithms that will be used in determining the content of chlorophyll a, and for determining TSS. Image accuracy test is done to find out how far the image can give information about Chlorophyll-a and TSS in the waters. The results of the image accuracy test will be compared with the value of chlorophyll-a and TSS that have been tested through laboratory analys is. The result of this research is the distribution map of chlorophyll-a and TSS content in the waters.
\end{abstract}

\section{Introduction}

One of the waters that has been contaminated by industrial waste and domestic waste is the waters of the Semarang Eastern Flood Canal which is the estuary of the river system of Eastern Flood Canal, Tambak Lorok (Kali Banger) and Kali Tenggang. The East Flood Canal River crossing the eastern city of Semarang is dense residential and industrial. Many industrial activities around this watershed (DAS). Among other things are the textile industry, foodstuff, plastic, karoseri, printing, pharmaceutical and herbal medicine, paint, furniture, lubricating oil, workshop, even there is a fish auction. These waters become domestic and urban waste disposal sites and industrial wastes generated by activities around the river basin [1].

With the amount of waste discharged along the river of East Canal Flood, Tambak Lorok and Kali Tenggang is so that there is need for information on the assessment of water quality in the estuary of the Eastern Flood Canal. One of the parameters for assessing water quality is Chlorophyll-a and Total Suspended Solid. Chlorophyll-a is a parameter used to determine the level of water fertility while Total Suspended Solid (TSS) is one of the parameters used to determine the level of water pollution. Because the Eastern Flood Canal is one of the estuary from the rivers system as dumping industrial waste. By knowing the content of Chlorophylla and Total Suspended Solid (TSS) in the waters of this
Semarang Eastern Flood Canal will be obtained information about water quality.

Distribution of Chlorophyll-a and Total Suspended Solid (TSS) can be estimated through remote sensing technology, such as from Sentinel-2A satellite imagery from remote sensing technology. Remote sensing technology can analyze the results of recording the spectral characteristics of water with water quality parameters. Remote sensing technology using satellite imagery offers a variety of facilities for obtaining data on fertility and water pollution compared to using more complex and costly laboratory tests. One of the benefits of using remote sensing technology is its wide coverage area, having an uncomplicated processing and low cost.

In Sentinel-2A satellite image processing to obtain information on fertility distribution data and water pollution, an algorithm is required to obtain suitable distribution value between image data and laboratory test data so that the selection of this algorithm is expected to get the value of distribution of fertility and water contamination matching In the study area. In this research there is one algorithms that will be used in determining the content of chlorophyll. The algorithm for chlorophyll use [2] algorithm and algorithms for determining TSS concentration is Sturn algorithm.

After obtaining the proper algorithm in determining the content of Chlorophyll-a and TSS concentration, then satellite image analysis was done to obtain real-time Chlorophyll-a and TSS distribution profile. Image accuracy test is done to find out how far the image can give information about Chlorophyll-a and TSS in the

\footnotetext{
* Corresponding author: sawitrisubiyanto66@gmail.com
} 
waters. The results of the image accuracy test will be compared with the value of Chlorophyll-a and TSS that have been tested through laboratory analysis.

\section{Literature Review}

\subsection{Water Pollution}

Definition of water pollution is the entry or inclusion of living creatures, substances, energy, and / or other components into the water by human activities, so that water quality decreases to some extent that causes water to not function according to its designation [3].

Water pollution caused by humans can arise from a variety of activities, whether intentionally or not, and in general greatly affect the environment resulting from pollution by living things. Pollution if not prevented or reduced is essentially harmful and detrimental to human beings in terms of health as well as in terms of social life or the survival of living things [4].

Water pollution affects organisms and plants in water bodies. In many cases this effect destroys not only individual populations and species but also natural biological communities. Water pollution is a global problem that requires immediate evaluation and water source policy at all levels. It is considered also the leading cause of illness and death [4].

\subsection{Phytoplankton}

Phytoplankton are tiny creatures that float on the surface of the water [5]. According to [6], phytoplankton is a plant that is often found throughout the mass of water in the euphotic zone, microscopic and has chlorophyll to form organic substances from inorganic substances through photosynthesis. Phytoplankton as an autotrophic organism produces oxygen to be utilized by other organisms, so that phytoplankton have an important role in supporting aquatic productivity. The existence of phytoplankton can be seen based on its abundance in waters, which is influenced by environmental parameters [7]. Apart from being a primary producer, phytoplankton is also a producer of dissolved oxygen in the waters for other organisms [8].

Phytoplankton is a biological parameter that can be used as an indicator to evaluate the quality and level of fertility of a water. Phytoplankton is also the largest contributor of oxygen in a waters. The importance of the role of phytoplankton as the initial binding of solar energy makes phytoplankton play an important role for aquatic life.

As a water organism, phytoplankton has many advantages as a biological benchmark that is able to show the level of ecological instability and evaluate various forms of pollution. Each type of phytoplankton differs physiologically and behaviorally to changes in environmental quality [10].

\subsection{Chlorophyll-a}

Chlorophyll comes from the Greek, which consists of two syllables, chloros which means green and phylum which means leaf. Chlorophyll captures life force or solar energy and is used to split $\mathrm{H}_{2} \mathrm{O}$ molecules into elements of $\mathrm{H}$ and $\mathrm{O}_{2}$, then combine them between elements $\mathrm{H}$ with $\mathrm{CO}_{2}$ gas and produce sugar or carbohydrates. From the process of photosynthesis is also produced byproducts of gas $\mathrm{O}_{2}$ [11].

Chlorophyll is better known as green leaf substance which is a pigment found in a producer organism that functions as a converter of carbon dioxide into carbohydrates, through photosynthesis. Chlorophyll has a chemical formula $\mathrm{C} 55 \mathrm{H} 72 \mathrm{O} 5 \mathrm{~N} 4 \mathrm{Mg}$ with $\mathrm{Mg}$ atoms as its center. Chlorophyll-a is one of the most decisive parameters of primary productivity in the ocean. The high distribution of low chlorophyll-a concentration is closely related to oceanographic condition of a waters. Some physical-chemical parameters that control and influence the distribution of chlorophyll-a are light intensity, nutrients (especially nitrates, phosphates and silicates). These physical-chemical parameter differences are directly the cause of the variation in primary productivity in some places at sea. In addition, "grazing" also has a major role in controlling the concentration of chlorophyll-a at sea [12]. Chlorophyll-a is an important component that is supported by phytoplankton and water plants which are both a source of natural food for fish. Chlorophyll-a is an active pigment in plant cells that play an important role in the ongoing process of photosynthesis [13].

\subsection{Trophic Water Status}

Eutrophication is a water enrichment with nutrients in the form of inorganic materials needed by plants and leads to an increase in primary productivity of waters. Nutrients in question are nitrogen and phosphorus. Eutrophication is classified into two, namely artificial or cultural eutrophication and natural eutrophication. Eutrophication is classified as artificial (cultural) eutrophication if nutrient uptake in waters is caused by human activity; And are classified as natural eutrophication if nutrient uptake in waters is not caused by human activity but natural activity [14].

Eutrophication is classified into four categories of trophic status [15], namely:

a. Oligotrophf; Is trophic status of lake water and / or reservoir containing low nutrient content, this status indicates that water quality is still unspoiled nature from nutrient sources $\mathrm{N}$ and $\mathrm{P}$.

b. Mesotroph; Is the trophic status of lake water and / or reservoir containing nutrients with moderate levels, this status indicates an increase in levels of $\mathrm{N}$ and $\mathrm{P}$, but still within the tolerance limit because it has not shown any indication of water pollution.

c. Eutrophic; Is the trophic status of lake water and / or reservoir containing high levels of nutrients, this status indicates that water has been contaminated by increased levels of $\mathrm{N}$ and $\mathrm{P}$. 
d. Hypereutrophic; Is the trophic status of lake water and / or reservoir containing very high levels of nutrients, this status indicates that water has been heavily polluted by increasing levels of $\mathrm{N}$ and $\mathrm{P}$.

Next on the criteria of trophic water status according to [16] are listed in the following Table 1.

Table 1. Water Status Trophic Criteria

\begin{tabular}{lr}
\hline \multicolumn{1}{c}{ Trophic Status } & Average Chlorophyll a $(\boldsymbol{\mu g} / \mathbf{l})$ \\
\hline Oligotroph & $<2,6$ \\
Mesotroph & $2,6-7,3$ \\
Eutroph & $7,3-56$ \\
Hypereutroph & $>56$ \\
\hline
\end{tabular}

\subsection{Total Suspended Solid}

TSS are suspended materials (diameter $>1 \mu \mathrm{m}$ ) retained on a sieve of miliopore with a pore diameter of $0.45 \mu \mathrm{m}$. TSS consists of mud and fine sand and microorganisms. The cause of TSS in the main waters is the soil erosion or soil erosion carried to the water body. TSS concentrations if too high will inhibit the penetration of light into the water and result in disruption of the process of photosynthesis. The spread of TSS in coastal waters and estuaries is influenced by several physical factors such as wind, rainfall, waves, currents, and tides [17].

The TSS concentrations in waters generally consist of phytoplankton, zooplankton, human waste, animal waste, sludge, crop residues and animals, and industrial waste [18]. Suspended materials in natural waters are not toxic, but if excessive amounts can increase the turbidity value which further inhibits the penetration of sunlight into the water column [17].

TSS is closely related to soil erosion and erosion of river channels. TSS is highly variable, ranging from less than $5 \mathrm{mg} . \mathrm{L}^{-1}$ is the most extreme $30.000 \mathrm{mg} . \mathrm{L}^{-1}$ in some rivers. TSS is not only an important measure of erosion in the river channel, it is also closely related to transport through the river system of nutrients (especially phosphorus), metals, and various industrial and agricultural chemicals [19].

\subsection{Pollution Index Determination}

According with the [20], University of Texas, A.S., proposed an index relating to a significant pollutant compound for a designation. This index is expressed as the Pollution Index used to determine the level of pollution relative to permitted water quality parameters [20]. This index has a different concept with the Water Quality Index.

The pollution index (PI) is determined for a designation, then it can be developed for some designation for all parts of the water body or part of a river. Water quality management on the basis of pollution index (PI) can provide input to decision makers in order to assess the quality of water bodies for a designation and take action to improve quality in case of quality deterioration due to the presence of pollutant compounds. PI encompasses a variety of independent and meaningful quality parameter groups [21].

Results of image data processing on Total Suspended Solid (TSS) concentration and subsequent laboratory test results are calculated by pollution index in accordance with Decree of State Minister of Environment No.115 Year 2003 about Water Quality Status as comparison with quality standard to know pollution level at point location The sampling. The formula for calculating the pollution index is as follows (1):

$$
\mathrm{PI}=\mathrm{Ci} / \mathrm{Lij}
$$

Where :

Ci: concentration of water quality parameters obtained from laboratory test results (TSS).

Lij: concentration of water quality parameters specified in the Water Quality Standard.

Evaluation of PI values are:

$0 \leq \mathrm{PI} \leq 1.0$ : meet the quality standard

$1.0<\mathrm{PI} \leq 5.0$ : lightly contaminated

$5.0<\mathrm{PI} \leq 10$ : moderately polluted

PI $>10$ : heavily polluted

\subsection{Cholorophyll-a Calculation Algorithm}

According to equation (1), algorithms that will be used in this research with the aim to get the best algorithm that can be used as formula of chlorophyll-a content processing in research area and can be used by multitemporal data of multilayered area study.

\section{Nuriya Algorithm et a}

The algorithm used for the determination of chlorophyll-a content using the Nuriya algorithm. The band ratio used to match the Sentinel 2A wavelength is Band Band, Band 5, and Band 4 band ratios. So in the processing of Sentinel $2 \mathrm{~A}$ image data the algorithm is used as follows (2):

$C=0,2818 \times\left(\frac{B 5+B 6}{B 4}\right)^{3,497}$

Information:

C: Chlorophyll-a concentration (mg / 1 )

B4: The reflectance value of channel 4

B5: Reflectance value of channel 8

B6: The channel reflectance value of 6

Because the algorithm uses the reflectance value, then the image data must be extracted first from the value of DN (digital number) to the value radiance. Then from the value of radiance to the value of Reflectance.

\subsection{TSS Concentration Determination Algorithm}

There are one algorithms that will be used in this research with the aim to get the best algorithm that can be used as a formula for processing Total Suspended Solid (TSS) concentration in research area and can be used by multitemporal data of Sentinel-2A study area. 


\section{Sturn (1988) Algorithms}

In this algorithm Sturn (1988) mapping suspended material. The Algorithm of TSS decrease as follows (3): TSS $(\mathrm{mg} / \mathrm{l})=0,4 *(\operatorname{Radb1}-\mathrm{Radb2})-0,88$ Where :

TSS $=$ Total Suspended Solid

Refb2 $=$ Band Reflectant Value 2

\subsection{Data Collection}

Data to be used in this research shown in Table 2 .

Table 2. Data and Data Source

\begin{tabular}{cllc}
\hline No & \multicolumn{1}{c}{ Data } & \multicolumn{1}{c}{ Source } & $\begin{array}{c}\text { Acquisi } \\
\text { tion } \\
\text { Time }\end{array}$ \\
\hline 1. & Sentinel-2A & $\begin{array}{l}\text { https://scihub.co } \\
\text { pernicus.eu/dhu } \\
\text { S/\#/home }\end{array}$ & $\begin{array}{c}\text { April } \\
2017\end{array}$ \\
& $\begin{array}{l}\text { Map of Semarang } \\
\text { City RBI Scale 1: }\end{array}$ & $\begin{array}{l}\text { BAPPEDA } \\
\text { Kota Semarang }\end{array}$ & 2001 \\
& $\begin{array}{l}\text { 25,000 } \\
\text { Chlorophyll-a and } \\
\text { TSS Concentration }\end{array}$ & $\begin{array}{l}\text { Field Survey } \\
\text { Results }\end{array}$ & April \\
13,2017 \\
\hline
\end{tabular}

In this study satellite image used is Sentinel-2A must be free from cloud. Map of Semarang City RBI Scale 1: 25,000 are used to extract basic elements of roads, rivers and administrative boundaries. In-situ measurements of Chlorophyll-a and TSS in the waters of the East Canal Flooding use randomly sampled.

The Chlorophyll-a and TSS concentration data from the field survey as shown in the Table 3 and Table 4 were obtained by sampling in the waters of the East Canal Flooding of Semarang City. Samples taken are at a depth of $25 \mathrm{~cm}$ from sea level. At the same time the sampling coordinates were also taken using GPS Handheld with accuracy of $\pm 2 \mathrm{~m}$. Table 3 is shown the result of Chlorophyll-a laboratory test result in sample locations.

Table 3. Content of Chlorophyll-a Laboratory Test Result

\begin{tabular}{ccccc}
\hline \multirow{2}{*}{ Date } & Name & \multicolumn{2}{c}{ Coordinates (m) } & Chlorophyll-a \\
\cline { 3 - 4 } & Point & $\mathbf{E}$ & $\mathbf{N}$ & (mg/l) \\
\hline \multirow{4}{*}{ April } & P1 & 437862 & 9232628 & 1,817540 \\
P2 & 437811 & 9232623 & 1,740550 \\
13, & P3 & 438927 & 9238418 & 0,086445 \\
& P4 & 439123 & 9233220 & 0,463155 \\
& P5 & 438675 & 9233356 & 0,155235 \\
& P6 & 440472 & 9234578 & 0,121995 \\
& P7 & 440182 & 9235726 & 0,035430 \\
\hline
\end{tabular}

Description: UTM Projection, Datum WGS 84, Zone 49 S

To select the appropriate algorithm used determination method using regression analysis between TSS result of algorithm processing with TSS value taken from field sample result. Table 4 is shown the result of TSS Concentration of Laboratory Test Results in sample locations.
Table 4. TSS Concentration of Laboratory Test Results

\begin{tabular}{ccccc}
\hline \multirow{2}{*}{ Date } & Name & \multicolumn{2}{c}{ Coordinates (m) } & $\begin{array}{c}\text { Total } \\
\text { Suspended } \\
\text { Point }\end{array}$ \\
\cline { 3 - 5 } & & E & N & $\begin{array}{c}\text { Solid } \\
\text { Concentration } \\
\text { (mg/l) }\end{array}$ \\
\hline \multirow{4}{*}{ April } & P1 & 437862 & 9232628 & 460 \\
13, & P2 & 436624 & 9233616 & 500 \\
2017 & P4 & 437733 & 9232880 & 580 \\
& P5 & 437941 & 9234370 & 520 \\
& P6 & 438675 & 9233220 & 420 \\
& P7 & 440472 & 9233356 & 760 \\
\hline
\end{tabular}

Description: UTM Projection, Datum WGS 84, Zone 49 S

\section{Results and Discussion}

\subsection{Results Chlorophyll-a Algorithm and Total Suspended Solid Algorithm}

Based on the processing of each algorithm obtained regression and RMSe results as Table 5.

Table 5. Regression Result and RMSe on each Chlorophyll-a Algorithm and Total Suspended Solid (TSS)

\begin{tabular}{lcc}
\hline Results & $\begin{array}{c}\text { chlorophyll-a } \\
\text { (Nuriya et al } \\
\text { Algorithm) }\end{array}$ & $\begin{array}{c}\text { Total Suspended } \\
\text { Solid (TSS) } \\
\text { (Sturn Algorithm) }\end{array}$ \\
\hline Regression & $93 \%$ & $85 \%$ \\
RMSe & $0,1992 \mathrm{mg} / 1$ & $41.03 \mathrm{mg} / 1$ \\
\hline
\end{tabular}

From result of regression and RMSe obtained that best Suspended Solid algorithm is Sturn with $85 \%$ regression and RMSe $41.03 \mathrm{mg} / \mathrm{l}$. For clorofil-a algorithm with regression value of $93 \%$ and RMSe of $0,1992 \mathrm{mg} / \mathrm{l}$. From RMSE these two algorithms meet the standards for the use of water pollution index determination.

\subsection{Analysis of Water Fertility Distribution}

Results of satellite image processing to determine the content of chlorophyll a using the algorithm Nuriya et al and classify using the trophic status of waters performed on sentinel years 2017 get the following results as Figure 1.

Table 6. Water Fertility Classification April 2017

\begin{tabular}{lrrr}
\hline \multicolumn{1}{c}{ Class } & \multicolumn{1}{c}{ Value } & Area (ha) & Percentage \\
\hline Oligotroph & $<2,6$ & 5274,04 & $88,83 \%$ \\
Mesotroph & $2,6-7,3$ & 265,33 & $4,47 \%$ \\
Eutroph & $7,3-56$ & 248,56 & $4,19 \%$ \\
Hypeutroph & $>56$ & 149,40 & $2,52 \%$ \\
\hline Total (ha) & & 5937,33 & $100,00 \%$ \\
\hline
\end{tabular}




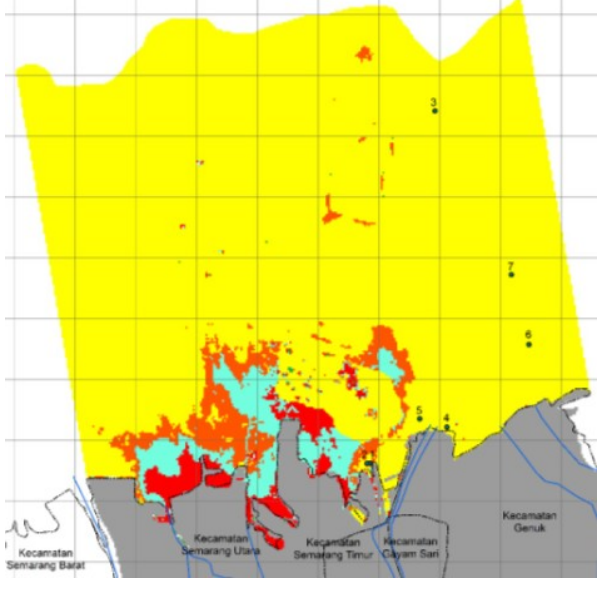

Figure 1. Distribution of Water Fertility in April 2017

From result of processing of chlorophyll concentration a using algorithm Nuriya et al in Table 6 got result of area of waters of flood waters of east canal of city of Semarang with classification of trophic status of waters, while result from classification is obtained oligotroph class of 5274,04 hectares occupy $88,83 \%$ From the research area, this oligotrophic class is spread evenly in all research areas, including river mouth, beach and loose seas. Mesotroph class of 265.33 hectares occupying $4.47 \%$ of the research area, this mesotrophic class is widely dispersed in the western seas of the harbor and is scattered over the loose seas. The eutrophic class of 248.56 hectares occupying $4.19 \%$ of the research area, this eutrophic class is spread over harbor, beach and ocean areas. While the hypereutrophic class of 149.40 hectares occupies $2.52 \%$ of the research area, this hypereutrophic class is spread over the estuary of the river, coastal and harbor areas.

\subsection{Analysis of Multipurpose Water Pollution}

After the processing is done on the reflectance value to the total suspended solid (TSS) concentration value using, the process of classifying the Total Suspended Solid (TSS) value to the pollution index value is calculated, The extent of the pollution area in accordance with the pollution index to obtain the following results is shown in Figure 2.

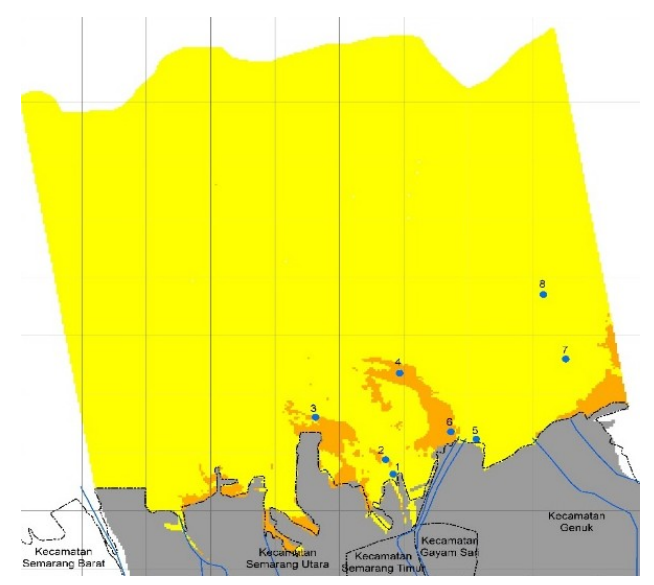

Fig. 2. Distribution of Water Pollution in April 2017
From the result of the processing of total suspended solid concentration in Table 7 is obtained the result of the extent of the flood waters of east canal flooding of Semarang city with the classification of pollution index, while the result of the classification is obtained lightly contaminated class of 5721,29 hectares occupying $96.18 \%$ From all the waters of the east canal flood that became the research site. While the polluted class was 227.52 hectares occupying $3.82 \%$ of the research area. The mild contaminated dispersion dominates the research area and it can be seen that the distribution of mild contamination lies almost in all research areas such as coastal areas and loose seas, whereas the polluted distribution is at the estuary of the rivers, beaches and harbor areas.

Table 7. Classification of Water Pollution April 2017

\begin{tabular}{lcrr}
\hline \multicolumn{1}{c}{ Class } & Value & \multicolumn{1}{c}{$\begin{array}{c}\text { Area } \\
\text { (ha) }\end{array}$} & Percentage \\
\hline Mild Polluted & $1<\mathrm{PI} \leq 5$ & 5721,29 & $96,18 \%$ \\
Medium Polluted & $5<\mathrm{PI} \leq 10$ & 227,52 & $3,82 \%$ \\
\hline Total (ha) & & 5948,81 & $100,00 \%$ \\
\hline
\end{tabular}

TSS is one element to determine the level of water pollution in a waters because it affects the entry of sunlight into the sea water. One of the factors used to determine water pollution is TSS which has a quality standard that has been established in [22] regarding the quality standards of seawater for harbor waters and sea water quality standards for marine biota, especially mangrove, because the area of this research area Harbor and planting mangrove plants so that the quality standard taken is the standard of seawater quality for port waters and marine biota. This further becomes the basis for classification based on the pollution index.

\section{Conclusions and Recommendations}

\subsection{Conclusion}

From a series of processes and analyzes in the previous chapter we can draw some conclusions as follows:

The content of chlorophyll a in the waters of the East Canal Flood viewed from the trophic status of the waters more dominated in the range $0-2.6 \mathrm{mg} / 1$, spread almost throughout the study area ranging from the coast, river mouth and open seas. For the smallest trophic status respectively were eutrophs (7.3-56 mg/1), mesotrophs (2.6-7.3 mg / 1), hypereutroph (> $56 \mathrm{mg} / 1)$, Spread over the estuary of the river and beach. As for the concentration of Total Suspended Solid (TSS) has a concentration of TSS dominated by the range of TSS concentration of $84-504 \mathrm{mg} / 1$, spread almost in all research areas. For the smallest concentration of TSS is in the range $504-5048 \mathrm{mg} / 1$ located at the estuary of the river and the port area. The suitable algorithm for the distribution of chlorophyll content in Eastern Channel Flood waters is Nuriya et al (2010) algorithm with determination coefficient of $93 \%$ And RMSe of 0.1992 $\mathrm{mg} / \mathrm{l}$. While the best suitable algorithm for the distribution of Total Suspended Solid (TSS) 
concentration in the waters of East Canal Flood Sturn (1988) algorithms with determination coefficient Of 85\% and RMSe of $41.03 \mathrm{mg} / 1$. Based on the results of the analysis it is known that the distribution of water fertility in the waters of the East Canal Flood in 2017 the trophic oligotroph status dominated the study area with a percentage of $88.83 \%$ and the lowest trophic status was in trophic hypereutroph status with a percentage of $2.52 \%$. While the distribution of water pollution with the category of contaminated light has 5721,29 hectares.

\section{Bibliography}

1. S.Y. Wulandari. Buletin Oseanografi Marina. 1(17) (2012)

2. H. Nuriya, Z. Hidayah, W.A. Nugraha. Jurnal Kelautan. 3(1):60-66 (2010)

3. Permenneg LH. Nomor 01 Tahun 2010. Tentang Laksana Pengendalian Pencemaran Air. (2010)

4. Dix, H. M. Environmental Pollution. John Willey and Sons Inc. Chischester. New York. (1981)

5. Yatim, W. 2003. Kamus Biologi. Yayasan Obor Indonesia. Jakarta.

6. Nontji, A. Plankton. Lembaga Ilmu Pengetahuan Indonesia-Pusat Penelitian Oseanografi. Jakarta. (2006)

7. Lukman, Sulastri, D.S. Said, T. Tarigan, and T. Widiyanto. Prosiding Seminar Nasional Limnologi 2006. Pusat Penelitian Limnologi-LIPI. Bogor.(2006)

8. Kamali. Komunitas Fitoplankton. Institut Pertanian Bogor. Bogor. (2004)

9. A. Astirin, A.D. Seryawan, and M. Harini, Jurnal. Biodiversitas, 3(2), 236-241 (2002)

10. A. Astirin, A.D. Seryawan, and M. Harini, Jurnal. Biodiversitas, 3(2), 236-241 (2002)
11. Sinurat, Studi Tentang Nilai Produktivitas Primer di Pangururan Perairan Danau Toba. Skripsi. Universitas Sumatera Utara. Medan. (2009)

12. Hatta, Hubungan Antara Klorofil-a dan Ikan Pelagis. Institut Pertanian Bogor. Bogor. (2002)

13. LIMNOTEK (2010) 17 (2) : 171-180. (2010)

14. Effendi, Hefni. Telaah Kualitas Air Bagi Pengelolaan Sumber Daya dan Lingkungan. (2003)

15. Peraturan Menteri Negara Lingkungan Hidup. Nomor 28 Tahun 2009. Tentang Daya Tampung Beban Pencemaran Air Danau Dan/Atau Waduk. (2009)

16. R.E Carlson, and J. Simpson. North American Lake Management Society. 96 pp. (1996)

17. Effendi, Telaahan Kualitas Air Bagi Pengelolaan Sumberdaya dan Lingkungan Perairan. Jurusan Manajemen Sumberdaya Perairan. Fakultas Perikanan dan Ilmu Kelautan.Institut Pertanian Bogor.hal 12-18. (2000)

18. US. Wiradisastra, delineasi Agro-ecological Zone. Bahan Kuliah Pelatihan Apresiasi Metodologi Delineasi Agroekologi. Bogor, 8-17 Januari 1996. Kerjasama Proyek Pembinaan Kelembagaan Penelitian dan Pengembangan Pertanian/AMRP dengan Fakultas Pertanian-IPB. Bogor. (1996)

19. Bird, Tony. Kimia Fisik untuk Universitas. Jakarta: Gramedia. (1987)

20. Nemerow, N.L.Scientific Stream Pollution Analysis. McGraw-Hill Book Co. (1974)

21. Keputusan Menteri Negara Lingkungan Hidup Nomor : 115 Tahun 2003 Tentang Pedoman Penentuan Status Mutu Air, Menteri Negara Lingkungan Hidup, Jakarta, 2003

22. MENLH. Keputusan Menteri Lingkungan Hidup Nomor: 51/MENLH/2004 Tahun 2004. Tentang Penetapan Baku Mutu Air Laut Dalam Himpunan Peraturan di Bidang Lingkungan Hidup. Jakarta. (2004) 